\title{
Beban Ganda Buruh Tani Perempuan di Jorong Limpato Nagari Kajai Kecamatan Talamau Kabupaten Pasaman Barat
}

\author{
Riva Dila Yarsiah, Alia Azmi \\ Prodi Pendidikan Pancasila dan Kewarganegaraan \\ FIS Universitas Negeri Padang \\ E-mail: rivadila24@gmail.com
}

\section{ABSTRAK}

Artikel ini bertujuan untuk mendeskripsikan fenomena beban ganda buruh tani perempuan di Jorong Limpato Nagari Kajai serta dampaknya terhadap kehidupan perempuan dan keluarga. Beban ganda merupakan salah satu bentuk ketidakadilan gender, terutama terhadap kaum perempuan pada keluarga miskin. Penelitian ini merupakan penelitian kualitatif dengan metode deskriptif. Informan dalam penelian ini sebanyak 18 orang yang ditentukan dengan menggunakan teknik purposive sampling. Jenis data dalam penelitian ini terdiri dari data primer dan data sekunder yang diperoleh melalui teknik observasi, wawancara, dan studi dokumentasi. Uji keabsahan data menggunakan teknik triangulasi. Analisis data dilakukan dengan tahap reduksi data, display data, dan mengambil kesimpulan/ verifikasi data. Hasil penelitian menunjukkan fenomena beban ganda yang dijalani oleh buruh tani perempuan dapat dilihat dari peran produktif, reproduktif, dan peran sosialnya di masyarakat. Sedangkan dampak beban ganda terhadap kehidupan perermpuan dan keluarga yaitu waktu untuk berkumpul dengan keluarga dan mendidik serta mengawasi anak menjadi terbatas dan kesulitan dalam pembagian waktu untuk menjalankan perannya menimbulkan tekanan bagi buruh tani perempuan, kurangnya interaksi buruh tani perempuan dengan anggota masyarakat, selain itu kegiatan sosial yang diadakan pada siang hari jarang dihadiri oleh buruh tani perempuan karena untuk menghadirinya mereka terpaksa meninggalkan pekerjaannya.

Kata Kunci: beban ganda, buruh tani perempuan, perspektif gender

\section{ABSTRACT}

This article aims to describe the phenomenon of the double burden of women farm workers in Jorong Limpato Nagari Kajai and their impact on the lives of women and families. Double burden is one form of gender injustice, especially against women in poor families. This research is a qualitative research with descriptive method. Informants in this study were 18 people who were determined by using purposive sampling technique. The type of data in this study consists of primary and secondary data obtained through observation, interviews, and documentation studies. Test the validity of the data using triangulation techniques. Data analysis is carried out with data reduction, data display, and drawing conclusions / data verification. The results of the study show the phenomenon of the double burden faced by 
women farm workers can be seen from their productive, reproductive, and social roles in society. While the impact of a double burden on the lives of women and families, namely time to gather with the family and educate and supervise children is limited and the difficulty in allocating time to carry out their roles creates pressure for women farm workers, lack of interaction between women farm workers and community members, besides social activities which is held during the day is rarely attended by female farm workers because to attend they are forced to leave their jobs.

Keywords: double burden, women farm laborers, gender perspective

\section{PENDAHULUAN}

Beban ganda perempuan bekerja memang tidak bisa dihindari dalam realitas masyarakat. Hal yang demikian sebenarnya tidak menjadi masalah jika suami ikut dalam membantu meringankan beban domestik yang harus ditanggung oleh pihak istri. Artinya ada pola relasi berbasis kemitraan antara suami istri. Namun jika tidak ada pola relasi berbasis kemitraan antara suami istri maka perempuan harus menjalani beban ganda yang merupakan salah satu bentuk ketidakadilan gender yang umumnya terjadi pada kaum perempuan. Beban ganda merupakan beban pekerjaan yang diterima salah satu jenis kelamin lebih banyak dibandingkan jenis kelamin lainnya (Hidayati, 2015:109). Beban ganda merupakan pekerjaan yang dilimpahkan kepada kaum perempuan, lebih lama pengerjaannya, apabila dilihat dengan pekerjaan untuk kaum laki-laki (Nunuk, 2004). Hal ini umumnya didorong oleh kondisi ekonomi yang lemah, pendapatan suami yang tidak mencukupi kebutuhan keluarga yang semakin meningkat menjadi pertimbangan perempuan bekerja

Hal yang sama peneliti temukan di Kabupaten Pasaman Barat yaitu di Jorong Limpato Nagari Kajai Kecamatan Talamau. Mayoritas penduduk Nagari Kajai bermata pencaharian sebagai petani dan buruh tani. Untuk lebih jelasnya berikut data mata pencaharian penduduk Nagari Kajai:

Tabel 1 Mata Pencaharian Penduduk Nagari Kajai.

\begin{tabular}{|l|l|l|}
\hline No & Mata Pencaharian & Jumlah Penduduk \\
\hline 1. & Petani Pemilik lahan & 1619 \\
\hline 2 & Petani Penggarap & 1067 \\
\hline 3. & Buruh Tani & 1325 \\
\hline 4. & Wiraswsta & 775 \\
\hline 5. & PNS & 219 \\
\hline 6. & TNI/POLRI & 13 \\
\hline 7. & Pegawai Swasta & 164 \\
\hline 8. & Lain-lain & 152 \\
\hline
\end{tabular}

Sumber: Kantor Wali Nagari Kajai 2020

Dari banyaknya masyarakat yang bermata pencaharian sebagai buruh tani menggambarkan bahwa keadaan ekonomi masyarakat di Nagari Kajai masih pada golongan menengah ke bawah. Salah satunya di 
Jorong Limpato, berdasarkan pengamatan peneliti di lapangan terdapat 92 orang buruh tani perempuan yang menjadi fokus dalam penelitian ini.

Berdasarkan wawancara peneliti dengan beberapa buruh tani perempuan di Jorong Limpato Nagari Kajai pada umumnya alasan perempuan yang bekerja sebagai buruh tani untuk memenuhi kebutuhan keluarga. Rata-rata pekerjaan dari suami mereka juga sebagai buruh tani, dengan penghasilan yang minim memotivasi perempuan ikut dalam mencari penghasilan tambahan. Namun tidak semua buruh tani perempuan memiliki suami, beberapa diantaranya ada yang berstatus single parent karena suaminya sudah meninggal dunia atau faktor perceraian sehingga menjadikan mereka sebagai tulang punggung keluarga demi kelangsungan hidupnya dan keluarga.

Para buruh tani bekerja mulai pukul 07.00 pagi hingga pukul 16.00 sore. Akses yang digunakan buruh tani menuju tempat bekerja yakni dengan jalan kaki. Mengenai pekerjaan sebagai ibu rumah tangga biasanya dilakukan oleh buruh tani sebelum atau sesudah pulang bekerja. Dari segi upah, buruh tani perempuan menerima upah dari pemilik kebun sebesar 40.000,00 rupiah per hari. Dengan jumlah upah yang demikian hanya mencukupi belanja sehari saja dan kadang tidak cukup karena upah yang diperoleh tidak lagi utuh lantaran telah dipinjam lebih awal oleh buruh tani kepada pemilik kebun untuk membeli kebutuhan pokok, belanja anak dan lain sebagainya.
Salah satu faktor yang menyebabkan kaum perempuan memilih pekerjaan sebagai buruh tani karena untuk memenuhi kebutuhan hidup yang semakin tinggi terlebih lagi ketika pendapatan diperoleh suami tidak dapat mencukupi kebutuhan hidup sehari-hari, maka secara otomatis peran istri untuk menunjang perekonomian keluarga sangat diperlukan (Suparman, 2018). Sehingga, faktor pendorong kaum perempuan sebagai buruh tani adalah karena faktor ekonomi (Masalamah, 2017) dan menambah penghasilan rumah tangga (Harini, 2011).

Berdasarkan uraian permasalahan diatas penelitian ini penting dilakukan jika hal yang demikian dibiarkan terjadi terus menerus akan membuat kaum perempuan terabaikan, jawaban dari hasil penelitian ini diharapkan nantinya buruh tani perempuan di Jorong Limpato Nagari Kajai lebih diperhatikan oleh pemerintah Nagari setempat.

\section{METODE PENELITIAN}

Jenis penelitian ini merupakan penelitian kualitatif dengan metode deskriptif yang di lakukan di Jorong Limpato Nagari Kajai Kecamatan Talamau Kabupaten Pasaman Barat. Informan dalam penelian ini dengan jumalah 18 orang yang ditentukan dengan menggunakan teknik purposive sampling yaitu buruh tani perempuan, suami buruh tani perempuan, anak buruh tani perempuan, pemilik lahan, dan tokoh masyarakat. Jenis data dalam penelitian ini terdiri dari data primer yang diperoleh secara langsung dari informan penelitian melalui observasi dan wawancara dan data sekunder 
diperoleh dari Kantor Walinagari Kajai, KAN Kajai, buku-buku, jurnal, skripsi serta data lainnya yang terkait dengan penelitian ini yang diperoleh melalui studi dokumentasi. Uji keabsahan data menggunakan teknik triangulasi. Analisi data dilakukan dengan tahap reduksi data, display data, dan mengambil kesimpulan/ verifikasi data.

\section{HASIL DAN PEMBAHASAN}

Berdasarkan hasil penelitian yang diperoleh dari lapangan yang disajikan sesuai dengan rumusan masalah yaitu bagaimana fenomena beban ganda yang dijalani oleh buruh tani perempuan di Jorong Limpato Nagari Kajai dan dampak beban ganda terhadap keluarga dan kegiatan sosial di masyarakat serta bagaimana keterlibatan suami buruh tani perempuan dalam pekerjaan rumah tangga. Fenomena buruh tani perempuan dalam menjalankan beban ganda di Jorong Limpato Nagari Kajai dapat dilihat dari peran yang dijalani oleh buruh tani perempuan baik itu perannya sebagai ibu rumah tangga (reproduktif), sebagai buruh tani perempuan (produktif) dalam memenuhi kebutuhan keluarga, hingga peran sosialnya di masyarakat.

Alasan utama perempuan bekerja sebagai buruh tani dikarenakan oleh kondisi ekonomi keluarga yang lemah. Dengan bekerja sebagai buruh tani upah yang diperoleh nantinya dapat dimanfaatkan untuk memenuhi kebutuhan keluarga yang semakin hari semakin meningkat. Dalam menjalankan peran produktif baik laki-laki maupun perempuan yang sudah bekeluarga sama-sama terlibat dalam memenuhi kebutuhan keluarga.
Akan tetapi di Jorong Limpato Nagari Kajai, konstruksi masyarakat memandang yang menjalankan peran ini ialah laki-laki. Di Jorong Limpato Nagari Kajai perempuan yang sudah menikah, laki-laki (suami) yang memiliki peran utama dalam memenuhi kebutuhan keluarga. Namun karena penghasilan suami tidak mencukupi kebutuhan keluarga maka perempuan juga ikut serta dalam memenuhi kebutuhan keluarga dengan bekerja sebagai buruh tani. Hal ini menjadikan perempuan menjalani beban ganda yang merupakan salah satu bentuk ketidakadilan gender.

Para buruh tani mulai menjalankan peran produktifnya sebagai buruh tani mulai dari pukul 07.00 hingga pukul 16.00 wib. Akan tetapi jika jarak tempat kerjanya jauh maka jam berangkat kerja harus dipercepat dari biasanya lantaran akses yang digunakan untuk berangkat kerja dengan jalan kaki. Jarak yang harus ditempuh untuk sampai ke tempat kerja sangat beragam. Namun jarak yang paling jauh yang pernah ditempuh oleh buruh tani perempuan hingga $4 \mathrm{Km}$. Di tempat kerja jenis pekerjaan yang dilakukan oleh buruh tani perempuan tergantung permintaan pemilik lahan seperti menanam, memupuk, hingga memanen buah jagung. Upah yang diperoleh buruh tani perempuan sebesar 40.000 rupiah per hari setiap kali bekerja yang nantinya digunakan untuk memenuhi kebutuhan keluarga, namun tidak jarang uang yang diterima tidak lagi utuh karena sudah terlebih dahulu dipinjam untuk kebutuhan keluarga. Fenomena yang menunjukkan alasan perempuan yang sudah menikah bekerja sebagai buruh tani untuk memenuhi kebutuhan 
keluarga yang memiliki kondisi ekonomi lemah juga terdapat dalam penelitian terdahulu oleh Zaril (2019:2) dan Kartika (2017).

Perempuan yang bekerja sebagai buruh tani dalam memenuhi kebutuhan keluarga menunjukkan bahwa perempuan menjalankan peran produktif. Seperti yang dijelaskan oleh Sudarta (2003:7) peran produktif ialah peran yang dilakukan oleh seseorang berkaitan dengan pekerjaan untuk menghasilkan barang/jasa. Selain bekerja sebagai buruh tani, beban kerja perempuan juga tidak terlepas dari pekerjaannya di rumah atau yang disebut sebagai peran reproduktif. Menurut Sudarta (2003:7) peran reproduktif yakni peranan yang berhubungan dengan tanggung jawab pengasuhan anak-anak dan tugas domestik seperti melahirkan, memelihara dan mengasuh anak, memasak, mencuci dan lain sebagainya. Dalam pengelolaan rumah tangga, peran perempuan sangat dibutuhkan. Tidak jarang bagi masyarakat awam pekerjaan ini dipandang sebelah mata, namun jika dilakukan pekerjaan ini dapat menguras tenaga dan waktu seharian. Peran reproduktif ini mulai dari memasak, mencuci, membeteskan rumah, mendidik anak dan lain sebagainya.

Berdasarkan hasil temuan di lapangan, perempuan buruh tani dalam menjalankan peran reproduktifnya seperti memasak, mencuci, membersihkan rumah sudah dilaksanakan secara maksimal. Akan tetapi peran reproduktif ini belum diterapkan secara optimal oleh perempuan buruh tani, terutama bagi mereka yang memiliki anak kecil harus ditinggal bersama neneknya, sehingga untuk mengetahui keadaan anak setelah pulang dari tempat kerja. Hal ini dikarenakan perempuan buruh tani menghabiskan waktu yang lama di tempat kerja. Sementara keterlibatan laki-laki (suami) dalam hal ini sangat rendah.

Hal yang demikian terjadi karena adanya konstruksi masyarakat Nagari Kajai bahwa yang mengerjakan pekerjaan rumah tangga dilimpahkan seutuhnya kepada istri. Sementara keterlibatan buruh tani perempuan dalam memenuhi kebutuhan keluarga dengan bekerja sebagai buruh tani tidak dapat mengubah perannya dalam pekerjaan rumah tangga. Dalam hal ini masyarakat Nagari Kajai memandang gender berdasarkan konstruksi masyarakat yang sudah menjadi budaya yang menimbulkan ketidakadilan gender bagi perempuan seperti yang disampaikan dalam penelitian terdahulu oleh Muhammad \& Winati (2013:105) bahwa ketidakadilan gender lahir karena adanya perbedaan peran dan posisi antara laki-laki dan perempuan yang dibentuk oleh faktor-faktor sosial maupun budaya.

Dalam menjalan aktivitasnya sebagai buruh tani dan kegiatan dalam rumah tangga, buruh tani perempuan juga harus menjalankan peran sosial. Sudarta (2003:8) menjelaskan peran sosial merupakan peran yang dilaksanakan oleh seseorang untuk berpartisipasi dalam kegiatan sosial di masyarakat seperti gotong royong dalam menyangkut kepentingan bersama. Peran sosial yang dijalankan oleh buruh tani perempuan di Jorong Limpato Nagari Kajai hanya pada kegiatan informal seperti membantu memasak hidangan atau makanan semabari mengahadiri acara 
pernikahan atau pesta-pesta lainnya pergi takziah apabila ada yang meninggal dunia.

Akan tetapi dengan waktu yang lama di tempat bekerja membuat perempuan buruh tani sulit dalam memilih waktu untuk bekerja dan kegiatan sosial di masyarakat. Dengan kondisi yang demikian membuat perempuan buruh tani mengikuti kegiatan sosial apabila sangat penting dan mendesak seperti kematian dan pernikahan kerabat, karena untuk menghadirinya mereka terpaksa meninggalkan pekerjaannya.

Keikutsertaan perempuan dalam sektor publik bekerja sebagai buruh tani untuk menambah penghasilan suami dalam memenuhi kebutuhan keluarga membuat waktu untuk berkumpul dengan keluarga dan mendidik serta mengawasi anak menjadi terbatas. Waktu yang dimilki buruh tani perempuan lebih banyak dihabiskan untuk bekerja. Hal ini menyebabkan kurangnya waktu bagi orang tua untuk mendidik dan mengontrol perkembangan anaknya. Fenomena yang demikian relevan dengan penelitian Kartika (2017) bahwa dampak yang ditimbulkan akibat perempuan bekerja sebagai buruh tani yaitu anak menjadi tidak terurus.

Selain itu tidak adanya pembagian tugas dalam anggota keluarga membuat perempuan buruh tani sulit dalam membagi perannya dalam melakukan pekerjaan dalam rumah tangga dan sebagai buruh tani yang mengakibat kurangnya waktu untuk istirahat yang dimiliki oleh perempuan buruh tani sehingga adanya tekanan bagi perempuan buruh tani perempuan. hal ini relevan dengan penilitian terdahulu yang dilakukanoleh Suparman (2018) yakni salah satu dampak beban ganda yaitu kesulitan untuk mengatur waktu dalam mengerjakan tugas domestiknya disamping itu juga harus bekerja sebagai buruh tani sehingga menimbulkan tekanan terhaap kesehatan buruh tani perempuan.

Keterlibatan perempuan dalam memenuhi kebutuhan keluarga juga membawa dampak yaitu kurangnya waktu untuk berkumpul dengan anggota masyarakat. Waktu senggang lebih mereka manfaatkan untuk beristirahat karena lelah setelah bekerja. Walaupun hubungan perempuan buruh tani dengan masyarakat sekitar baik dan tidak ada konflik. Akan tetapi, kegiatan sosial yang diadakan di siang hari jarang diikuti oleh buruh tani perempuan seperti keorganisasian PKK dan wirid yasin sedangkan pada acara pernikahan dan kematian itu diikuti apabila yang mengadakan kerabat atau tetangga dekat. Jika acara tersebut diadakan pada tetangga jauh, maka buruh tani perempuan memilih untuk pergi di sore atau malam hari untuk sekedar menghadirinya. Hal ini relevan dengan penelitian yang dilakukan oleh Nurjannah (2011) bahwa dampak negatif dari beban ganda yaitu waktu untuk berkumpul dengan anggota masyarakat menjadi terbatas, hal ini karenakan lamanya waktu yang dihabiskan di tempat kerja.

\section{KESIMPULAN}

Beban ganda yang dijalani oleh buruh tani perempuan di Jorong Limpato dapat dilihat dari perannya sebagai ibu rumah tangga, buruh tani dalam memenuhi kebutuhan keluarga, 
serta peran sosialnya dalam masyarakat. Beban ganda tersebut membawa dampak terhadap kehidupan perempuan dan keluarga yang tidak terlepas dari adanya konstuksi masyarakat yang menganggap bahwa laki-laki (suami) selain sebagai kepala keluarga, juga berperan sebagai pencari nafkah. Sedangkan urusan pekerjaan rumah tangga merupakan tanggung jawab perempuan (istri). Akibatnya keterlibatan laki-laki (suami) dalam pekerjaan rumah tangga sangat rendah, hal ini menjadi sebuah ketidakadilan terutama bagi perempuan yang memiliki taraf ekonomi yang rendah dan merupakan suatu bentuk ketidakadilan gender terutama bagi perempuan.

\section{DAFTAR PUSTAKA}

Harini, Y. B. (2011). Peranan Perempuan dalam Perekonomian Keluarga dengan Memanfaatkan Sumber Daya Pertanian. Jurnal AGRISEP, 10 (1): 138-153.

Hidayati, N. (2015). Beban Ganda Perempuan dan Bekerja (Antara Domestik dan Public). Jurnal MUWAZAH, 7(2): 108-118

Kartika, O. D. 2017. Peran Ganda Perempuan Buruh Tani di Desa Bojong, Kecamtan Mungkid, Kabupaten Magelang: Universitas Negeri Yogyakarta

Muhammad, S dan Winati G. 2013. Pengaruh Ketimpangan Gender Terhadap Strategi Bertahan Hidup Rumah Tangga Buruh Tani Miskin Di Desa Cikarawang. Jurnal Sosiologi Pedesaa. 1 (2): 100-111

Musallamah, U. (2017). Studi tentang Buruh Tani Perempuan di Desa Sukamaju Kecamatan Singngi
Hilir Kabupaten Kuantan Singngi. Jurnal FISIP, 4 (1): 1-14. Murniati, P Nunuk. 2004. Getar Gender (Perempuan Indonesia dalam Perspektif Sosial, Politik, Ekonomi, Hukum, dan HAM. Magelang: Indonesia Tera

Nurjannah. 2011. Dampak Peran Ganda Pekerja Perempuan terhadap Keluarga dan Kegiatan Sosial Di Masyaraka (Studi Terhadap Pekerja Perempuan Pada Industri Rumah Tangga Kerajinan Kulit Di Dusun Manding Sabdodadi Bantul). Skripsi: universitas negeri Yogyakarta

Sudarta, W. 2003. Pembangunan Wanita Berwawasan Gender. Jurnal Studi Gender Srikandi, 3 (1)

Suparman. (2018). Peran Ganda Istri Petani. Jurnal AKRAB JUARA, 3 (3): 42-55.

Zairil, M. G. 2019. Peranan Petani Wanita dalam Meningkatkan Perekonomian Keluarga di Desa Sakra Selatan. Jurnal Manajemen dan Ilmu Pendidikan, 1 (2): 1-11 